Relations industrielles

Industrial Relations

\title{
Reddy, Y.R.K., Trends, Patterns and Impact of Strikes
}

\section{Basu Sharma}

Volume 48, numéro 1, 1993

URI : https://id.erudit.org/iderudit/050844ar

DOI : https://doi.org/10.7202/050844ar

Aller au sommaire du numéro

Éditeur(s)

Département des relations industrielles de l'Université Laval

ISSN

0034-379X (imprimé)

1703-8138 (numérique)

Découvrir la revue

Citer ce compte rendu

Sharma, B. (1993). Compte rendu de [Reddy, Y.R.K., Trends, Patterns and Impact of Strikes]. Relations industrielles / Industrial Relations, 48(1), 201-202.

https://doi.org/10.7202/050844ar

Tous droits réservés (C Département des relations industrielles de l'Université Laval, 1993
Ce document est protégé par la loi sur le droit d'auteur. L’utilisation des services d'Érudit (y compris la reproduction) est assujettie à sa politique d'utilisation que vous pouvez consulter en ligne.

https://apropos.erudit.org/fr/usagers/politique-dutilisation/ 
initiés en confirmant ce qu'ils savaient par intuition. Soyez désormais avisés que les arbitres américains, à l'instar de leurs collègues canadiens, sont dans l'ensemble des hommes, blancs, âgés, instruits et la plupart du temps retraités. Les femmes arbitres, quant à elles, pénètrent lentement mais sûrement dans le métier.

De cette recherche, il faut aussi souligner la remarquable base de données sur les arbitres et leur pratique arbitrale. Ces données permettront éventuellement de mesurer l'évolution de la pratique de l'arbitrage. Cette étude a enfin permis de dégager des informations très précises auxquelles il est toujours intéressant de se comparer. $\AA$ coup sûr, il s'agit d'un bon document d'archives.

Claire Brassard

Phillips \& Vineberg, Montréal

Trends, Patterns and Impact of Strikes, by Y.R.K. REDDY, Hyderabad, India, Spade Publications, 1990, 114 p., ISBN 81-85491-00-3

The book is about strike trends, their patterns, seasonality, and inter-industry and inter-state propensities for strike activities in India, together with their impact and their policy implications.

In Chapter I, the author has addressed the issues related to definition of industrial conflict, reporting requirements, and computational and measurement problems. In addition, he has developed a portfolio of strike measures for the purpose of empirical analysis of strike activities to follow in the subsequent chapters of the book. Elements included in the portfolio are strike frequency, participation, loss, and duration. Appropriate deflators and possible ratios to standardise these strike measures have also been discussed in this chapter.

Chapter II is a test of Ross-Hartman hypothesis on strike trends, and a reassessment of "withering away of strikes" prediction. This has been done in two ways: (i) by examining the Indian evidence, and (ii) through examinations of comparative data for 14 countries including India. The objective of the comparison was to find relative ranking of the Indian strike situation for the periods 1978-1980 and 1984-1986. Countries used for international comparison include both developed and developing ones. Except for strike frequency, the author found an increasing trend in strike activities in India for the periods examined. In fact, "India ranked first and second among the fourteen countries, in respect of mandays lost per 1,000 employees, during the two periods analysed. Similar was the case in respect of the duration measure. The average duration for India was 25 days in period B as against the lowest of 1.2 days in the case of S. Korea" (p. 32).

In Chapter III, the author has examined causes, duration, and results of strikes during the period from 1951 to 1986 . The analysis indicates that the wage disputes have decreased over the years while strikes in other categories have increased. One of the explanations given for the decline in wage strikes is the setting up of Wage Boards by the government for all the major industries. However, it has been conjectured that disputes in the other categories might have been used increasingly as trade-off for wage bargaining. As to the duration, the author observes a steady decline of shorter duration strikes but an increasing trend in longer duration ones. Explanation for this development 
is lacking though. In Chapter IV, the author has examined the question of seasonality of strikes, looking at all the three classical measures of strike activities. It is commendable that he has constructed a new measure called the " Seasonal Irregular Ratios," and has used these ratios to determine interrelatedness of the seasonal factors.

Inter-industry propensities to strike are examined in Chapter V. In fact, this Chapter is primarily a test of Kerr-Siegel hypothesis that "the factor of location of the worker in the society determines his strike propensity and this location is largely influenced by the industrial environment." However, sectoral uniqueness and frequency of negotiations rather than the technical context are what seem to explain the inter-industry propensities to strike in India. As the author suggests, "Identical industries in technical contexts (for example, coal and iron ore mining) have evidenced different propensities. On the other hand, it is possible that the frequency of negotiations... will define the scope for strikes"' (p. 84). Inter-state propensities to strike are examined in Chapter VI. Of the fourteen States, West Bengal, Kerala and Maharastra appear to be the most strike-prone states in India, except for frequency for which Orissa, Bihar and Rajasthan rank among the top three. But there is no coherent explanation of these inter-state propensities to strike.

Issues and concerns related to the impact and implications are addressed in Chapter VII. The impacts have been discussed following a concentric view. That is to say, the discussion follows from the micro level to the macro level-impact on workers, on organisations, on public and on the economy as a whole. This is followed by a discussion of the implications. Issues addressed here include strike rights, the question of social responsibility, strikes and the challenges of economic development and the global competitiveness.

Notwithstanding the above, this reviewer has some concerns and criticism to note. First, political unionism has been the order of the day in India. There are casual references to this in the book. However, the author has not paid adequate attention to union types and their orientations while examining consequences of strikes. Second, there has also been a lot of new literature on strikes and their consequences. This new literature has not been adequately reviewed and integrated in the analysis. Third, even though the book is quite readable as it is well-written and data are plotted graphically for visual inspection, there are quite a few cases of typos and carelessness in the book (e.g., mondays for mandays on p. 54; frame-work for Framework on p. 48; Impact and Implications for Inter-State Propensities [the running heading] on p. 91). Fourth, the author has identified and detected various tendencies and patterns in strike activities in India. Some of these patterns and tendencies go against the established theories and hypotheses. However, alternate arguments and reasons to explain these anomalies have not been fully developed.

All in all, this book has definitely made some contribution to advance our understanding of strike activities. It has attempted to systematically examine strike activities in one of the largest democracies of the world. It has also indicated the implications of strikes for economic development and global competitiveness. Scholars and policy makers alike will find the book very useful.

Basu SHARMA 